\title{
Nothing Fancy: Focus and Commitment Earn National Award for Iowa State
}

Allyn Jackson

Every other summer the Department of Mathematics at Iowa State University hosts a Research Experiences for Undergraduates (REU) program that draws outstanding math majors from around the nation, many of them women and many from underrepresented minorities. Every month the department holds a dinner where women PhD students, together with faculty mentors, can discuss the special challenges women mathematicians face. Every week department chair Clifford Bergman shows up at the tea for undergraduates held in Sprague Lounge, a recently redesigned space where students can meet and hang out. And every weekday the Math Help Room offers free, walk-in tutoring for any student who needs it.

These activities are not new or wildly innovative; they are "nothing fancy," as former chair and current associate vice president Wolfgang Kliemann put it. But together they result in a synergy that

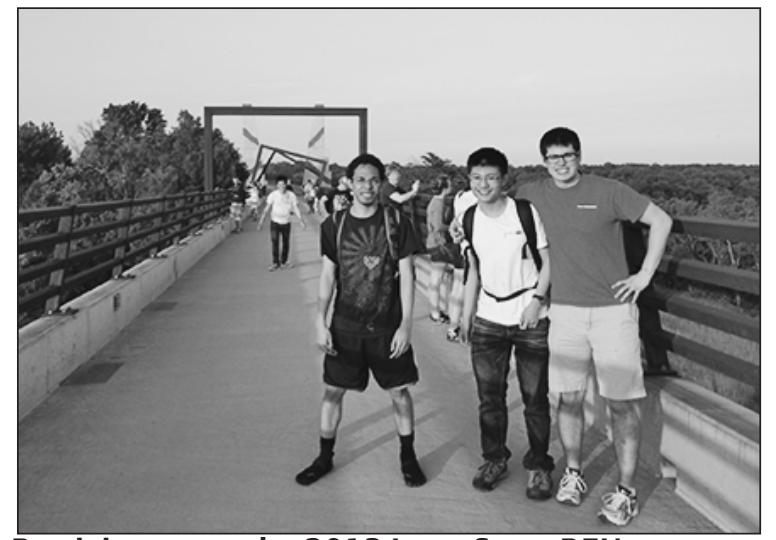

Participants at the 2013 lowa State REU on a trip to the High Trestle Trail Bridge.

has made the Iowa State mathematics department a stand-out on its campus and a leader nationally.

Allyn Jackson is senior writer and deputy editor of the Notices. Her email address is axj@ams . org.

Photos courtesy of the Iowa State University Department of Mathematics.

DOI: http://dx.doi.org/10.1090/noti1255
The key ingredients of the department's success are commitment and focus: the department took a serious look at its responsibilities, established key priorities, and marshalled the talents of its faculty. For its outstanding achievements and for providing an example of excellence on many fronts, Iowa State has received the 2015 AMS Award for an Exemplary Program or Achievement in a Mathematics Department.

\section{New Directions}

The Iowa State mathematics department has always been a congenial place with a faculty active in research and dedicated to its students. But in the 2000s, it began to move in some new directions that enhanced its sense of purpose. For example, in 2001, on the initiative of then-chair Justin Peters, the department became a founding member of the Alliance for the Production of African American PhDs in the Mathematical Sciences. The purpose of the alliance was to forge connections between the Iowa regents universities and HBCUs (historically black colleges and universities). In 2004 Peters and his colleague Leslie Hogben received an REU site grant from the National Science Foundation (NSF); the two have collaborated on this highly successful REU ever since. One can also sense the department's focus and determination in a self-study, carried out in 2007, which made a serious assessment of the progress the department had made on recommendations from an outside evaluation carried out eight years earlier.

In 2008, while Kliemann was chair, the department engaged in extensive discussions about its responsibilities and made a decision to focus on two main priorities. The first was undergraduate teaching. "For incoming students in mathematics, at least at large public institutions, what they see [in their first mathematics course] is their most important impression of the institution," said Kliemann. "Why? Because that course makes or breaks their careers." The department devoted a great deal of time to examining why students sometimes flounder in these courses 
and what can be done to make the courses more successful for more students.

\section{Focus on Undergraduate Teaching}

One course that stood out was precalculus, in which many students ended up in the DFW category-getting a D or F in the course or withdrawing altogether. At Iowa State the DFW rate in precalculus sometimes went as high as 60 percent. Like many universities, Iowa State had been herding students through precalculus as cheaply as possible by delivering it over the Web. The thinking was that all students had seen the material in high school, so they needed only a refresher. "Anyone who wanted to take it could just enroll," recalled Bergman. The message to students: "You're on your own, and lotsa luck getting through it."

The department concluded that this approach was not working. Putting forth Kliemann's point about how crucial students' first university math course is, the department successfully argued for additional resources from the university to deliver the course in a more traditional-and more expensive-format emphasizing person-to-person contact. The result was an immediate 20 percent rise in retention. The department also got funds to hire a new faculty member, Timothy McNicholl, who took on the task of redesigning the precalculus course. A new and better placement examination was instituted, and all incoming freshman are required to take it. For the placement exam, "the most important thing is to get all the academic advisors on board," Bergman remarked. Students who place into precalculus often argue that they already took it in high school, and their advisors also might not see the need to repeat the course. "We have to convince the advisors that if this placement exam is telling us [their students] are not ready for calculus, don't put them in calculus," Bergman said. "We are making progress on that."

Precalculus was not the only course the department revamped; indeed, it has taken a serious look at all but one of its offerings and made changes designed to improve student learning. It also worked carefully on how to match instructors with courses. As a result of these efforts, the department saw DFW rates fall below 30 percent in key beginning courses. To provide consistent focus on these issues, in 2009 the department founded the Center for Excellence in Undergraduate Mathematics Education, directed by faculty members Elgin Johnston and Heather Bolles. The center studies performance of students in departmental courses, engages faculty and graduate students on teaching issues, and maintains communications with other departments that rely on courses in the mathematics department. The center also coordinates the department's outreach activities; these range from working with high schools and community colleges on articulation issues to hosting a high school mathematics competition.

As the department worked to improve undergraduate teaching, the number of mathematics majors soared from about 130 in 2008 to about 300 today. Exactly why the rise occurred is not entirely clear, but the special efforts the department has made to provide a welcoming home to math majors have surely helped. The department created Sprague Lounge, a gathering place for undergraduates that includes an entire wall painted with white board paint. In 2011 two young mathematicians, Steven Butler and Xuan Hien Nguyen, were hired. Butler has a special flair for working with majors, and he organizes the weekly undergraduate tea in Sprague Lounge as well as game nights and other activities that promote a sense of community. An experienced juggler, Butler taught a class on the mathematics of juggling in fall 2013. Together with her colleague Heather Bolles, Nguyen organized a Math Club for Future Teachers, which promotes networking and career development. Nguyen also redesigned the department's orientation course for math majors to devote less attention to policies and procedures and more to career options and to giving students a sense of the different fields of mathematics.

Last fall the Iowa State mathematics department taught 10,500 students. Delivering excellent instruction to all of them is a massive enterpriseand a big responsibility. Meeting that responsibility requires a mathematics department to continually evaluate its courses to be sure they are working well for students. "We did this for course after course," said Kliemann. Right now on the Iowa State campus the mathematics department is recognized as "the 'poster child' department for showing how to put together a program that works for a very large number of students but is still responsive to the individual students."

\section{Commitment to Diversity}

The second main priority the department identified in 2008 was the need to increase diversity,

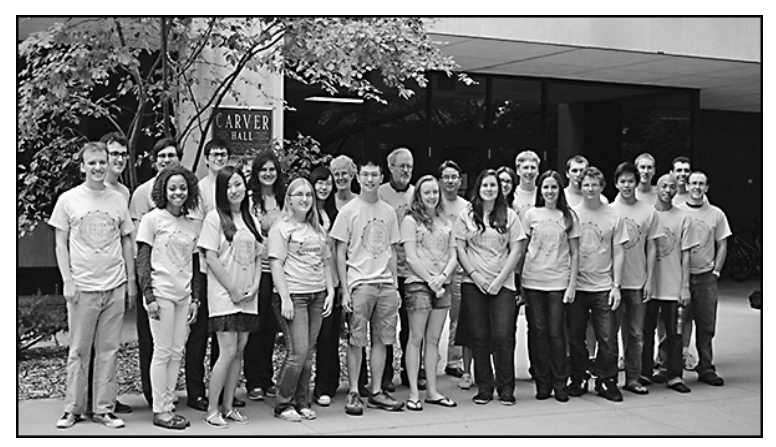

Participants in the 2013 REU at lowa State. Two faculty members are seen in the back row: Leslie Hogben (left) and Justin Peters (right). 


\section{What a Supportive Environment Can Do: Leslie Hogben}

Leslie Hogben is the granddaughter of Lancelot Hogben, the zoologist and medical statistician whose name is a household word in mathematics, largely due to his 1936 book Mathematics for the Million. As a child growing up in Iowa, Leslie corresponded regularly with her grandfather, who lived in England. They discussed a wide variety of topics, including mathematics. She finally met him when her family made a trip to Britain after her senior year in high school, and she got to know him better when she spent her junior year in college at the University of Warwick. "He was quite a character," she recalled. "He was a renaissance man with very broad interests."

Probably the biggest influence leading Leslie Hogben to make a life in mathematics was the rich and stimulating environment in which she grew up. Her father, Adrian Hogben, a medical doctor and researcher, did science experiments with her when she was 3 years old. Her mathematics teacher at University High in Iowa City, Gerardus ver Voort, recognized her talents early on. In her junior-year mathematics class, four days of the week were devoted to the standard material, and one day was for exploring. One exploration centered on was then known as the 4-color conjecture. In just one class period, students proved the 6-color version. "It took us more than a month, but we actually proved that 5 colors were enough," Hogben recalled. "Of course, that was known at the time, but we discovered a proof for ourselves."

After receiving her $\mathrm{PhD}$ from Yale University in 1978, under the direction of Nathan Jacobson, Hogben took a position at Iowa State University. At that time anti-nepotism rules were still the norm, so her husband, Mark Hunacek, also a mathematician, could not get a job in the same department. So he went to law school and embarked on a career as an assistant attorney general. When Hogben had a child, she decided she wanted to stay home full-time. The Iowa State mathematics department supported this decision by allowing her to take leave for two years and to work part-time for four years, and then it welcomed her back full-time. Although she had tenure, under the circumstances the department could have gotten rid of her pretty easily. It never tried. "I was incredibly naive and incredibly lucky when I picked this department," she said.

Hogben's background and experiences bring a deep understanding of how important mentoring and a supportive environment are to budding mathematicians. She has for years been at the center of the department's efforts to nurture students, and her appointment in 2008 as diversity director has given her the time to expand those efforts and to reach out more systematically to underrepresented groups. Hogben emphasizes that what the department has achieved in this regard does not depend on her alone and is very much a team effort. Nevertheless, her leadership has had a big impact.

Her advice to graduate programs looking to improve? "Don't lower the standards, but take active steps to help students meet those standards." Many studies have shown that if changes are made that positively influence the success of all students, those changes end up having a disproportionate impact on the underrepresented. "Most students are much more alike than they are different," she observed. "Most have an adjustment period to graduate school. We help them become full members of the department....For this we provide a friendly, welcoming, and supportive environment."

particularly in the graduate program. "We didn't have minority faculty, we didn't have many women, we didn't have many minority graduate studentsthat was exactly the situation when I took over as chair in 2008," Kliemann recalled. "We live in the middle of Iowa. There isn't much diversity!" The state is 90 percent white. Nevertheless, the department took this priority to heart and found a couple of effective avenues to pursue.

One was to utilize contacts it had made as a founding member of the Iowa Alliance. By 2006 that program had expanded into its current incarnation, the National Alliance for Doctoral Study in the Mathematical Sciences. Now usually referred to simply as the Math Alliance, this organization sponsors the annual Field of Dreams Conference and collaborates with other national programs that aim to increase diversity in the mathematical sciences. The Iowa State department began to work more closely with the Math Alliance. Faculty made trips to minority-serving institutions in a variety of locations, including Puerto Rico, Texas, and Mississippi.

With these new connections, the Iowa State department ramped up recruiting efforts for its REU, with a focus on bringing in more students from minority-serving institutions and students from institutions that traditionally do not send their mathematics majors to graduate school. At the time, the department had two sources of funding for its REU: The NSF grant, and a grant from the Iowa Alliance to support minority students. They integrated students from the two funding sources, 
bringing together "the best young undergraduate mathematicians from around the country and the best young minority undergraduate mathematicians from around the country," Kliemann said. "It turned out this was a fantastic idea."

The REU has been a great success. Of the sixty students who participated in the four REUs held since 2009, 25 percent are members of underrepresented minorities and 40 percent are women. Of those who are no longer undergraduates, 57 percent have enrolled for a $\mathrm{PhD}$ in mathematics (60 percent of the minorities and 52 percent of the women). Another 18 percent enrolled in graduate programs in science, technology, or engineering. In that same time period, thirteen papers based on work done in the REU have appeared in or have been accepted by mathematics journals.

The REU has also had a positive impact on the department's graduate program. The department has seen an increase in the number of applications to the graduate program, as well as a rise in the number of PhDs awarded, from five in 2002 to thirteen in 2013. "Students are aware of our department as a good place for graduate school," Bergman said. "You can't underestimate how much the REU has helped [in this regard]. We are on the radar screens of all the best math undergraduates in the country. It's really been a great thing."

In 2009 the department jumped with both feet into the diversity effort, committing funds to create a new position of diversity director. Hogben was appointed to the post. She already had a part-time position as the diversity director for the American Institute of Mathematics, so the departmental position allowed very efficient use of her knowledge and skills. The department gave her time off from teaching and a travel budget so that she could concentrate on making connections with minority-serving institutions and recruiting students. Now that those efforts have started to pay off, Hogben is spending more time on mentoring students. She emphasizes that this has not been a one-woman show: several members of the department also made recruiting trips and have put a great deal of time and attention into the mentoring and support of students.

\section{No "Sink or Swim" Here}

Today about 15 percent of the graduate students in the Iowa State mathematics department are members of minority groups. The department also actively recruits women graduate students; in spring 2014, 34 percent of the $\mathrm{PhD}$ students were women, and women comprised 50 percent of the $\mathrm{PhD}$ students who started in fall 2014. The efforts to increase diversity among the graduate students succeeded partly because the department has been putting a great deal of effort into improving conditions for all graduate students. The signal clearly is: If you are accepted here as a graduate student, we will do all we can to ensure you succeed. The "sink or swim" approach that has been common in mathematics $\mathrm{PhD}$ programs is absent here.

In their first year, graduate students get basic advice from the director of graduate education, such as which courses to take, and they are also assigned a second mentor, who helps with other aspects, such as understanding the culture of mathematics and negotiating the ins and outs of the department. More-advanced graduate students act as peer mentors to the newer students.

Together with her colleague from the Department of Statistics, Karen Dornin, Hogben set up an EDGE Mentoring Cluster, which promotes mentoring of women graduate students by faculty. The clusters are part of the EDGE (Enhancing Diversity in Graduate Education) program, which has been running since 1998 and which received the AMS Mathematics Programs That Make a Difference Award in 2007. The success of the Iowa State EDGE cluster led the department to establish a new cluster called co-EDGE, which has similar aims and is open to all students, male and female. The department also has a mentoring cluster for minority students called MOCA (Mathematicians of Color Alliance). MOCA was started by Michael Young, who was hired in 2014 as an assistant professor after having spent several years in the department on a postdoctoral fellowship from the Alliance for Building Faculty Diversity in the Mathematical Sciences.

The department has a lot of infrastructure to shepherd graduate students into research early on. This came about spontaneously as faculty began working with groups of students and led to the development of an Early Graduate Research course. In addition, graduate students help out with the REU, which allows them to take part in the enthusiasm and excitement of the group research going on there and also to gain valuable experience mentoring younger students. As a result, said Hogben, "Our graduate students tend to have a lot of research experience before they write their theses." The department could increase the number of graduate students but consciously keeps it at about 80 so that each research-active faculty member has an average of 2.5 students. With that ratio, the department can do its best for all of the students.

The department has developed a "brand," Kliemann said: It is a large department when it comes to teaching, "but it is a relatively small and cozy department when it comes to graduate studies." Probably the most important factor in developing this brand is that the students who have studied in the department speak well of it. And the admiration goes both ways. "We have a great group of graduate students," Bergman said. When Iowa State hosted an AMS Sectional Meeting in April 2013, the graduate students enthusiasti- 
cally participated in many of the sessions and also pitched in to act as guides and helpers. Said Bergman, "They were fantastic representatives for Iowa State."

In improving the graduate program, "we didn't do anything fancy," Kliemann said. The department makes a commitment to support students through their studies and to give them the information they need to be successful after finishing. Said Kliemann, "All of this contributes to the impression that we care about our students. And we do."

\section{Collegiality and Teamwork}

A mathematics department in a large university like Iowa State has many responsibilities, and meeting them takes contributions from the whole faculty. How does Iowa State get all the faculty on the same page and working together? One way is by acknowledging that, in meeting the department's multiple responsibilities, faculty members will contribute in different ways and to different extents. In some departments, faculty discuss responsibilities by saying to each other, "You should be doing this, you shouldn't be doing that," Kliemann noted. "We don't do that here."

About a dozen years ago the university began requiring "position responsibility statements," and the mathematics department has found them to be quite useful. Worked out between the chair and each individual faculty member, a position responsibility statement spells out what that faculty member will concentrate on. The statements are revisited and updated annually. A major determinant of what appears in the statement is the interests of the faculty member. The statements help the department chair to assess the potential and interests of the faculty and to match them with the department's responsibilities. When the chair uses these statements well, "lots of people get a chance to do what they would like to do," Kliemann said. Of course, having an effective chair is key to making it all work, and the department has had a succession of effective chairs who have led not by preaching what to do but by doing.

The Iowa State department has achieved a great deal, not through revolutionary changes, not by implementing a cure-all program, and not by overloading a single faculty member who "does it all." Rather, it has relied on tried-and-true ideas, sound educational principles, and dedicated teamwork. "I don't think we did anything that special," said Kliemann. "We were just absolutely serious. When we discussed something and understood that it was important to us, we were serious in implementing it."

\section{Tenth Anniversary of the Exemplary} Award

This is the tenth anniversary of the AMS Award for an Exemplary Program or Achievement in a Mathematics Department. In winning the award this year, the Iowa State Mathematics Department joins an outstanding group of top-quality departments-including its neighbor, the mathematics department at the University of Iowa, which received the award in 2007. (A full list of departments that have received the award appears in the official announcement of the 2015 award, in this issue of the Notices.) These award-winning departments work hard every day to deliver excellent teaching, to go the extra mile to support their students and faculty, and to reach out to users of mathematics on the campus and beyond. Not every department can aspire to be a Harvard or a Princeton or a Berkeley. But every department can gain by emulating the example set by those that have received the Exemplary Award.

As a group, the award-winning departments demonstrate the sense of responsibility and the good will that the mathematical sciences community holds towards the other communities it serves and towards society. Complaints that mathematicians don't care about students or teaching, that they are stuck in their own ivory tower, are common. But increasingly, such complaints ring hollow-and the departments that have received this award over the past decade are one reason why. They count among the community's best exemplars and its best ambassadors. 